\title{
THE ROLE OF SOCIAL MEDIA IN PURCHASING BEHAVIOUR OF YOUNG DIGITAL CUSTOMERS IN POLAND
}

\author{
Milena Le Viet-Błaszczyk* (1) http://orcid.org/0000-0003-1237-4205 \\ Juliusz Lerman** (i) http://orcid.org/0000-0003-3330-2630
}

\begin{abstract}
Background. The dynamically developing technology and changing system of interpersonal communication has modified the customers' approach to the process of making purchasing decisions. The literature has even developed the concept of a new customer - a digital one. The market situation forced companies to look for effective modern tools for their marketing communication. One of such tools to reach digital customers is social media.
\end{abstract}

Research aims. The aim of the article is to indicate the role of social media in the purchasing process of Polish digital customers aged 18-26.

Methodology. The conclusions presented in the article are the result of an analysis of quantitative and qualitative research, which consisted of a survey with 140 respondents and of 6 individual in-depth interviews.

Findings. The conducted research has shown that social media have a significant role in customers' purchasing decisions. They influence the perception of the brand by customers but also the purchase of specific products. Based on the research results, it can be assumed that SM functionalities that shorten the purchasing process will be developed in the future, and the role of social media in the purchasing process will grow.

Keywords: social media; digital customer; consumer choice theory, marketing.

JEL Codes: M3, M30, M31, M37.

* Master of Arts, Łódź, Poland. E-mail: milena.le@unilodz.eu.

** Master of Science, Łódź, Poland. E-mail: juliusz.lerman@unilodz.eu. 


\section{INTRODUCTION}

Globalisation and the technological revolution have a significant impact on the functioning of today's economy (Mazurek, 2019). The current market situation has developed so much that science has begun to define a new customer, the digital one (Bassiouni \& Hackley, 2014). More and more purchasing decisions are made not only on the Internet, but especially using social media (Miotk, 2013). Brands are competing in creating more and more interesting, attention-grabbing content, which is designed not only to arouse interest, but also to immediately sell or redirect to e-commerce websites (Kreft, 2015).

These circumstances lead to a reflection on a new perception of the consumer choice theory, which has been discussed widely in literature, but rarely in the context of the latest technologies (Stephen, 2016). Social media are also becoming a more and more frequently researched area. However, they are growing so fast and introducing new features so quickly, that researchers have not yet had enough time to analyse this phenomenon comprehensively.

In this article the authors have undertaken an attempt to measure the role of specific factors in social media that influence purchasing behaviour of a digital customer. The study was based on desk research and the authors' own quantitative and qualitative research.

\section{BASIC ISSUES OF CONSUMER THEORY IN THE CONTEXT OF THE MODERN MARKET}

According to the theory of consumer choice, a customer considering the possibility of purchasing a particular good is limited by his or her income and by the price of that product (Caban, 2001). The purchase involves determining the utility of the goods that can be acquired and comparing this value between competing products (Mansfield, 2002). Utility is subjectively ranked by the purchaser (Marczak, 2001). Customers may differ in their assessment of the utility level of individual goods. In addition, customers typically purchase more than one product or service, so that the final purchase decision involves determining the total utility value of the goods purchased, resulting from the combination of the utility of 
the components of the individual products or available substitutes (Milewski \& Kwiatkowski, 2005).

Apart from usefulness of the chosen goods, the customer's purchasing behaviour is also influenced by his planning to create savings for future purchases. The accumulation of savings is limited by the amount of the customer's income and usually involves giving up the purchase of lower-order goods (Krugman \& Wells, 2006). Saving involves making a purchase, but postponed, which means that lower-order goods are not sufficiently useful to the customer and are not purchased. Similarly, the time spent by the customer on leisure significantly affects the wealth of their wallet and their purchasing decisions. Most household income comes from the sale of labour (Nojszewska, 2010). Thus, if a customer limits the sale of their work, considering that more time to rest is more useful to them than the purchase of certain goods, the range of products he or she purchases will naturally change, and the customer will most likely give up purchasing goods he or she does not consider necessary. Essentially, the aspect of income, both in terms of gaining and targeting certain transactions, has an undeniable impact on the customer's decision-making as regards the volume and structure of consumption. However, other factors in this process must not be forgotten as well (Caban, 2001).

Today's market is characterised by a remarkably high competition and a multitude of substitutable goods (Urbanek, 2016). Also, the activities of governments and non-governmental organisations aiming to build welfare states gradually eliminate the problems of the lower classes of society, associated with low affluence and difficulties in obtaining normal goods (Golinowska, 2005). Examples of these are social benefits, state pension schemes, or ideas for introducing basic income. From this perspective, non-remunerative factors influencing customer choices are becoming increasingly important.

According to the consumer choice theory, income is a key but not the sole factor influencing purchasing behaviour (Rumińska-Zimny, 2003). The volume and structure of consumption is also influenced by non-income factors, which can be divided into objective and subjective ones (Caban, 2001). Demographic factors, such as age or gender, but also socio-cultural factors are understood as objective. The subjective ones are derived from the consumer's disposition, character traits, and individual worldview. They may also result from the desire to stand out, aspirations to belong to a particular social group, and the like. 
As the consumer profile changes over time as a result of globalisation and socio-cultural changes, so does the priority given to the various non-income factors influencing the purchasing behaviour in various sectors. As a typical example of this shift, it can be mentioned that the change in the social position of women has significantly influenced their purchasing choices (Pikuła-Małachowska, 2015).

In the era of progressive digitisation, consideration should be given to the designation, naming and systematisation of non-remunerative factors influencing purchasing decisions (Chaffey, 2016). Communication between the company and the customer is increasingly shifting from the real world to the virtual world, which affects consumers' subjective feelings about the course of the purchase process (Kotler, Kartajaya, \& Setiawan, 2017). Building relationships with buyers, their loyalty and the image of their own brand, that is the key aspects related to subjective non-revenue factors, may look different than before for companies in many industries (Mazurek, 2019). The ongoing technological revolution has a significant impact on the functioning of today's economy as well as on consumer purchasing decisions (Drucker, 2000). In the scientific literature, this has resulted in the definition of a new type of buyer - a digital customer (Fiore, 2008).

\section{THE DIGITAL CUSTOMER}

For a digital customer, the Internet has become a particularly important part of life (Gregor \& Kaczorowska-Spychalska, 2018). This kind of customer is able to gather information on the offers of competing companies in a noticeably short time. Websites and applications for searching and comparing products available on the market allow to find exactly what they are looking for. In addition, these customers have the opportunity to consult the choice with the opinions of thousands of other Internet users, who have purchased a particular product or intend to do so (Kotler et al., 2017). In theory, this should rationalize customers' choices and optimise their spending, but paradoxically, such great ease in finding products considered highly useful and relying on the opinions of unknown, often anonymous people, may undermine this rationality (Mistewicz, 2011).

This type of customer not only relies on the opinions of other Internet users when making purchasing decisions, but also expresses 
their opinions and recommends their favourite brands. They acquire and analyse information, which they later share with other users co-creating content on the Internet. The digital customer is proactive and engages not only in interaction with other customers, but also advises and communicates directly with the company producing goods that are of interest to him or her (Kreft, 2015).

An important feature of the digital customer is his or her orientation towards an individual approach in product design (Ratalewska $\&$ Wierzbicka, 2017). This type of customer requires personalised goods and a simplified way of satisfying needs. Due to the ease of searching for and comparing products of competing brands, they also require high quality and an extremely fast reaction time when responding to their inquiries.

It should also be noted that the new type of customer lives in the era of information overload (Hatalska, 2008). They are unable to select all important and necessary information and messages. Therefore, in addition to rational arguments, their purchasing behaviour is often influenced by emotions and impulses. Both marketing messages of companies and recommendations of Internet users are most effective when they evoke strong emotions in the customer (Mistewicz, 2011). They are different from thousands of other messages, which makes them the most attractive in the minds of the customers.

Due to the activity of the digital customers in recommending and discussing individual goods, and taking into account their requirement for quick reactions from the producer and the need to have distinctive personalised products, social media seem to be the optimal environment for companies to reach potential customers. Their specificity allows both for quick, individual reactions to the signalled needs, as well as for creating internally homogeneous communities.

\section{USING SOCIAL MEDIA TO REACH THE DIGITAL CUSTOMER: THE PERSPECTIVE OF COMPANIES}

Digital customers gain knowledge about products or services from many various sources (Gregor \& Kaczorowska-Spychalska, 2018). Social media (SM) - a group of web-based applications that are built on ideological and technological foundations of Web 2.0, and enable creation and exchange of user-generated content (Kaplan \& Haenlein, 2010), has 
recently become one of them. The reason why social media have become a place to gain knowledge about products may be their fast expansion (Batra \& Keller, 2016). Since 2004, when they started to function on a mass scale (Mazurek, 2019), they had still had an impact on almost every aspect of personal and corporate life (Kaplan \& Haenlein, 2011). In this way, they are constantly extending their influence, both on customers and companies (Mazurek, 2019).

There are many reasons for the brand's exploitation of social media, such as: accessibility and reach, the option of modification and, at the same time, durability of the message (Grębosz, Siuda, \& Szymański, 2016), the opportunity to improve the competitive position (Chan-Olmsted, Cho, \& Lee, 2013), the potential to gain knowledge about the needs and desires of the customer (Kotler \& Keller, 2013), and then the opportunity to build relationships with them, participation of the customer in brand communication (Constantinides, 2014), the possibility of implementing innovative ideas (Erdogmus \& Cicek, 2012), increase in exposure and traffic, generation of transitions (e.g. to a website) and sales growth (Stelzner, 2019). Moreover, the potential for new value of social media use is still growing. The leading players on the SM market compete and try to constantly introduce new functionalities based on the latest technological solutions.

There are currently three levels at which social media are used in the organization, these are (Mazurek, 2019):

1) the operational level, the aim of which is to achieve marketing objectives,

2) a tactical level intended to generate conversions,

3) the strategic level, meaning the impact on the functioning of the organisation.

This text will focus on the first two levels, with emphasis on the second. This one is closely related to the transformation of the SM user into a customer who, after seeing the content, is going to make a transaction in the future (Macik, Mazurek, \& Macik, 2012). The basis of social media operations is the ongoing learning of the structure of the community of users present there. This is the foundation for identifying the details of the target groups and the content directed to them. 


\section{CHARACTERISTICS OF SOCIAL MEDIA USERS}

During an era of digital transformation, the consumption of numerous and varied messages has become a routine for many people (Olejniczuk-Merta, 2015). Internet users were given great opportunities to gain knowledge and competences, and in consequence to build relationships not only with people but also with brands (Gregor $\&$ Kaczorowska-Spychalska, 2018). At the same time, it became the task of companies to encourage the customers to such contact in a unique and interesting way (Kotler et al., 2017). The network's residents have begun to demand an even more individual approach and understanding of needs, as well as inclusion in the process of creating and building value. They have also become more market-conscious and more involved - not only through interactions with brands, but also by giving and searching for recommendations of other people in the digital world (Gregor \& Kaczorowska-Spychalska, 2018).

There are more and more active Internet users in Poland. The high potential of using SM in sales activities is proven by the size of the social media market and its development. The "Digital 2020" report (Hootsuite \& WeAreSocial, 2020) and Stelzner's (2019) research have shown, among other things, that in 2020:

- the number of Internet users totals 4.54 billion, which represents $59 \%$ of the global population, representing an increase of $7 \%$ in comparison to January 2019,

- social media is used globally by 3.8 billion users, which is $49 \%$ of the global population. The number of users has increased by over 9\% (321 million new users) since last year,

- in January 2020, Poland had 30.63 million Internet users. The number of Internet users in Poland increased by 686 thousand (2.3\%) between 2019 and 2020 ,

- social media are used by 19 million Poles, which means an almost $8 \%$ growth over 9 months,

- the social media penetration in Poland is $50 \%$,

- the most popular SM platforms are Facebook, Instagram, Twitter, LinkedIn, YouTube, Pinterest, Messenger, and Snapchat.

All platforms identified above respond in their own way to the needs of the digital customer. Facebook transmits content to recipients via groups, the main feed, additional advertising columns, as well as via 
Messenger. In this way, it takes advantage of the fact that the digital customer can acquire a huge amount of information in one moment (Belk \& Llamas, 2013). Instagram has the increasingly popular Instastories option (Stelzner, 2019), which is a feature that allows users to publish photos or videos visible for only 24 hours. This functionality responds to the needs of the digital customer, who is always in a hurry. At the same time, by means of numerous possibilities of interaction with the recipient, Instastories also becomes a place of social listening and even co-creation of products or services. Snapchat also provides similar possibilities. Twitter, meanwhile, allows to quickly review the main messages written by people or institutions. Therefore, for some people it can become a kind of substitute for a daily newspaper. Pinterest and YouTube refer to the current pictorial culture (Woźniakowski, 2014). The second one may also be a better alternative to "traditional" television for some people.

Summing up, the communication between the company and the customer moves from the real world to the virtual one, which affects the process of purchase (Kotler et al., 2017). The social media market is thus becoming a place with the potential to influence digital customers and their purchasing decisions.

\section{METHOD}

The aim of the article is to indicate the role of social media in the purchasing process of Polish digital customers aged 18-26. The study was conducted in two phases.

The first phase was a quantitative study conductedin the period from January 2020 to March 2020. The research tool was a questionnaire, distributed among Polish respondents using both Computer Assisted Web Interview (CAWI) and Paper And Pencil Interview (PAPI) techniques, containing 13 questions on the scope of using SM, respondents' knowledge of the possibilities of purchasing via social media, shopping preferences in social media, and metric questions and identification of a group of digital customers.

According to the "Digital 2020" report, in Poland the most numerous group of social media users are generations $\mathrm{Z}$ and $\mathrm{Y}$, which means people aged 18-34 (Hootsuite \& We Are Social, 2020). Due to the aim of the empirical study, which was to indicate both the current situation 
and trends, the focus was put on the 18-26 age group, which can be defined as the Z generation (Żarczyńska-Dobiesz \& Chomątowska, 2014).

The survey considered the answers of 140 respondents (of whom $61 \%$ were women and $39 \%$ were men), who indicated that they used the Internet for shopping purposes. The most numerous groups were citizens of villages (33\%) and cities with a population of over 500,000 $(33 \%)$. Next were people registered in areas up to 50,000 (18\%), between 50,000 and 100,000 (9\%) and between 100,000 and 500,000 residents (7\%).

The method adopted in the second part of the study was in-depth interviews (IDI), aimed at supplementing the data resulting from the quantitative study and their critical analysis with digital marketing specialists. The in-depth interview allows for reaching subjective motivations and patterns of an individual, isolated from the influence of other respondents. Thanks to this, the respondents' statements can be based on their experience, not only on theories contained in the literature. Additionally, the research topic requires the collection of qualitative data in order to analyse in depth the determinants of the impact of social media on the purchasing behaviour, which can significantly enrich the analysis of quantitative material.

The interviews addressed issues related to the assessment of the impact of social media on customers' purchasing behaviour. The respondents were also asked how in their opinion trends in this subject would develop in the foreseeable future.

There were six respondents in the interview - three women and three men. Each of them was interviewed separately. The respondents represented companies and agencies dealing with Internet marketing and profile management in social media companies. The sample selection was deliberate, motivated by professional experience in the digital marketing industry. Among the respondents all represented middle or senior management positions in their organisations.

\section{THE IMPACT OF SOCIAL MEDIA ON THE PURCHASING DECISIONS OF YOUNG DIGITAL CUSTOMERS}

The above paragraphs underline the significant role of social media in the purchasing process of digital customers. In order to measure 
the current impact in the group of young Poles, and, in addition, to learn about the premises accompanying purchasing decisions in social media, the following research hypotheses have been assumed:

4) Polish digital customers aged 18-26 consciously search for and discuss products in social media.

5) Polish digital customers aged 18-26 are aware of and make use of social media purchasing opportunities.

In the questionnaire, the respondents were asked to indicate the main reasons for social media activity. The responses are shown in Figure 1.

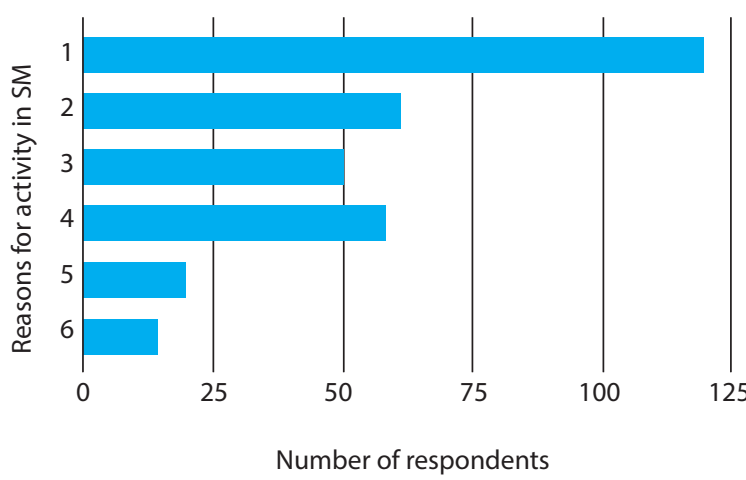

1. I am looking for information products/services

2. I follow what my friends recommend

3. Thanks to the social media I am able to make purchasing decisions faster

4. I ask my friends there for their opinions on products/services

5. I recommend products there to others

6. Other

Figure 1. Reasons for activity in social media

Source: own study.

As the most common reason for activity in SM they strongly stated searching for information about products and services. This point was indicated by $86 \%$ of people (with the possibility to select more than one reason). It can therefore be concluded that Polish Internet users consider SM to be a reliable source of knowledge. Additionally, 36\% of people declared that thanks to social media, they are able to make purchasing decisions faster. The above answers suggest that digital customer behaviour is not only planned but also rational. Moreover, among the surveyed respondents, the vast majority (80\%) admitted observing the brand/company profile in social media. This means that digital customers of the Zgeneration consciously agree to have their advertising content displayed. Thus, the answers show that it is impossible to reject the first hypothesis. 
As a complementary measure, those who indicated an affirmative answer were also asked to specify their motivation, which has been shown in Figure 2.

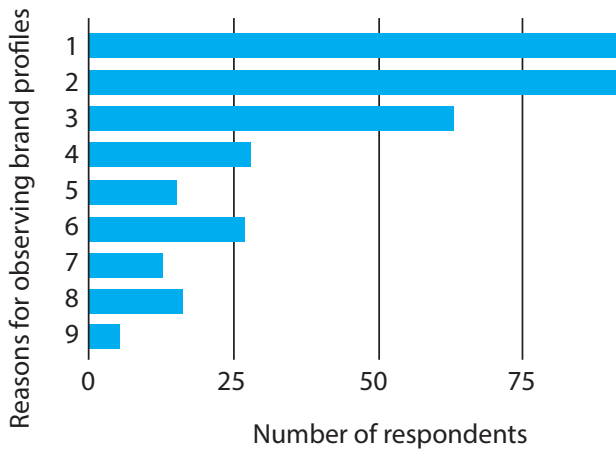

Number of respondents
1. I like the brand/company

2. Due to information about new products, promotion, company life

3. I have access to special offers, discounts for fans

4. Due to he interesting content

5. Due to the possibility of winning prizes in competitions

6. This is a costumer service centre I can ask questions, make comments

7. I can add comments and discuss

8. I have access to information about the company's pro-social activities

9. Another reason

Figure 2. Reasons for observing brand profiles

Source: own study.

The majority of the respondents, having multiple choice, indicated three main reasons for observation: liking the brand, obtaining information about new products, promotions, company life, and special offers and discounts for fans. The last two motivators, which were indicated by $65 \%$ and $45 \%$ of respondents, strictly refer to the willingness to purchase.

A lack of observing brands in social media does not necessarily mean a lack of contact with the content created by them (facebook.com). As expected, almost all (99\%) of the respondents met with a brand/product/ service advertisement in social media. Knowledge of the specifics of social media allows to presume that the remaining $1 \%$ of the respondents are a group of people who unconsciously or consciously indicated the wrong answer. The reason could be, for example, very infrequent use of SM or lack of awareness that the displayed content was commercial. This presumption is based on the knowledge that brands promote their products very intensively in social media. Based on the analysis conducted by the authors, there are so many business profiles and their posts that it is almost impossible to avoid any advertising messages when spending longer time in SM. However, the result indicating that 
$99 \%$ of respondents encountered ads and that $80 \%$ consciously agreed to them, confirms both hypotheses of the article.

Despite the extensive use of the Internet for shopping purposes (Łopaciński \& Łysik, 2016), it still cannot be considered that young customers prefer buying online. Indeed, when asked "What kind of shopping do you prefer?", $48.5 \%$ of respondents indicated online shopping, and $51.5 \%$ chose the traditional store. The reasons for this situation can be seen in several factors, including companies which do not yet have an online store, or people viewing a trip to the shopping centre as a form of entertainment. The verification of general customer preferences was the first step in verifying purchases made via social media. It turned out that almost $90 \%$ of the surveyed met with the possibility to buy a product using the SM platform. However, even though they were aware of the functionalities that allow them to buy via social media, only $18.6 \%$ used them. The results are presented in Figure 3.

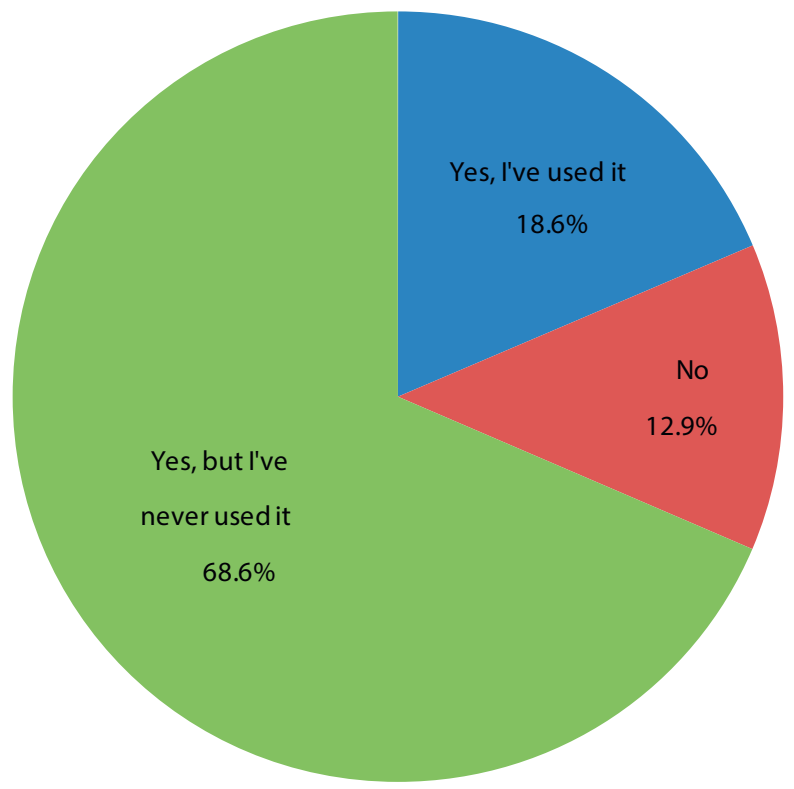

Figure 3. Purchase via SM platform.

Source: own study. 
The reason for this may be the relatively short time of such tools' existence. For example, the "Shop" section on Facebook has been gaining popularity among Polish companies since 2018. Furthermore, the fact that $18.6 \%$ of consumers have made purchases through SM, can be considered a relatively high result. Since 66 people indicated a preference for online shopping, almost $40 \%$ of these users (39\% to be precise -26 respondents) used social media to buy. The answers therefore indicated that it is impossible to reject the second hypothesis. It is also worth adding that the difference between those who know and those who use SM purchases may change in the future - it is worth observing the trend and making another study of this issue in the near future (approximately in a year).

In order to verify the role of social media in purchasing decisions, it was verified whether customers buy products they have seen in social media. The survey showed that $84 \%$ of respondents have done so. Additionally, considering the respondents' answers to previous questions analysed so far, it can be concluded that customers are aware of the influence of SM on their purchasing decisions. The results again indicated that it is impossible to reject the second hypothesis.

Brands try to influence customers' buying decisions in various ways. The responses so far showed that information about discounts and new products have the greatest role in this area. However, it has been checked whether such an influence can also be achieved by building relations between the company and the customer, or more precisely by moderating the profile. As many as $75 \%$ of the people considered that if a brand responds to fans' comments or messages, it encourages them to buy its products or services.

In conclusion, social media play an important role in shaping the purchasing decisions of young digital customers. It is in the SM where they search for and discuss products, where they come into contact with brand advertisements, buy products they find out about from social media, and also use social media tools to make the purchase. Therefore, since there is no rejection of any of the hypotheses, it must be stated that social media influence purchasing decisions of digital customers aged 18-26.

Interviews with specialists in the digital marketing industry confirmed the conclusions resulting from the analysis of quantitative research results. Respondents express a unanimous opinion that social media have an influence on making purchasing decisions. In 
the opinion of the respondents, the market communication of brands in social media is mainly of an image-building nature and is supposed to strengthen the relations between the customer and the brand, but people who run company profiles in social media strive to maximize the sale of products.

According to the respondents, appropriate communication in social media allows to reach customers with the message more effectively than communication using traditional tools. Among other reasons, this is due to the fact that in a traditional store the customers have only the help of a sales person at their disposal, while on the Internet they can rely on the comments of other users as well as on advice of online influencers. As one of the respondents notes, social media reduce the post-purchase dissonance, because even if the customer is not fully satisfied with the purchase, they rationalize it from the angle of opinions of friends or influencers who use the product.

Additionally, as another respondent explains, social media, similarly to pay per click advertisements, remarketing, or email marketing, provide an opportunity to create an accurate insight of the customer. This later allows for a precise division of customers into segments and the appropriate selection of tools and market communication of the company to a given customers segment. The effects of social media marketing are visible in real time, which allows for possible corrections of messages, which in regard to traditional media would be a time-consuming and costly process.

\section{TRENDS IN THE IMPACT OF SOCIAL MEDIA ON FUTURE PURCHASING BEHAVIOUR}

According to all respondents of interviews, the role of social media in purchasing processes will continue to grow. As the main factor, they mention the introduction of solutions in social media allowing for shopping, even without providing any specific application. As an example, the Checkout functionality, currently tested by the Instagram portal, was given. At the same time, some respondents hope that social media will not go in the direction of full conversion into shopping platforms. According to one of the respondents, a great value for companies is the ability to create communities around the brand in social media. If acompany would give up dialogue and image activities on these 
platforms, leaving the profile only as a sales channel, the gain would not outweigh the loss.

Another respondent notes that not only functionalities that allow for a start-to-end transaction in one application can be considered as sales channels. As an example, he cites sales groups on Facebook, which simply associate people and companies selling products and potential customers, while the order and payment for the product itself are already outside the portal. As another respondent states, the situation is similar with Facebook's Marketplace functionality. A customer wishing to purchase a product is referred to an external website, which is a given brand's online store. In the opinion of the majority of respondents, such tools can be called shopping platforms, while remembering that the largest social networking sites work on solutions that shorten the purchasing process to a minimum, such as the already mentioned Checkout.

As far as the products that the respondents believe are most likely to be sold effectively through social media are concerned, the opinions are divided. One of the respondents stated that, in his opinion, customers will be willing to buy cosmetics through social media, especially the ones they know, but it will be more difficult for them to buy clothes. Another respondent has just indicated the textile industry as the one with the greatest potential. Another respondent noted that electronics and spare parts for cars and other machines, for example, seem to be the optimal products to sell through social media. However, the majority of respondents agreed with the statement that one of the industries which may be most difficult to introduce through this type of sales channel is FMCG, especially companies offering food products.

Some respondents believe that the Polish market is not yet ready for a revolution in the form of buying in stores existing only in social media. At the same time, they emphasise that if social media shopping platforms are part of a coherent and comprehensive market communication of a brand, they have great potential to gain additional customer segments, for example the customers from the $\mathrm{Z}$ generation. One of the respondents notes that the best confirmation of the potential of social media sales is the fact that some companies already do so and are successful in their industries. He mentioned the brands: Varlesca, Hellobody, and Daniel Wellington as examples. 


\section{CONCLUSIONS}

The technological revolution has had a significant impact on consumer purchasing decisions (Drucker, 2000). There is even a term in the scientific literature defining a new type of buyer, namely, the digital customer (Fiore, 2008), meaning a person for whom the Internet is an important part of life. Marketing should use the latest technologies and techniques to meet the challenges of the marketing environment in the twenty-first century (Kotler \& Keller, 2013). Thus, since frequent use of the Internet has become an everyday reality for customers, companies whose aim was to reach these recipients must be there as well (Gregor \& Kaczorowska-Spychalska, 2018).

In recent years, social media have become one of the key tools of marketing communication (Mazurek, 2019). The conducted research has shown that they have a significant impact on customers' purchasing decisions. Social media influence the perception of the brand by customers, but also the purchase of specific products. Social media play an important role in shaping the purchasing decisions of young digital customers aged 18-26. It is in the SM where they search for and discuss products, where they come into contact with brand advertisements, buy products they find out about from social media, and what is more, they use social media tools to make the purchase. Functionalities are also introduced to contain the entire purchase process within one application. Based on the results of the research, it can be assumed that in the future SM functionalities that shorten the purchasing process will be developed, and the role of social media in the purchasing process will grow.

\section{REFERENCES}

Bassiouoni, D.H. \& Hackley, C. (2014). Generation Z children's adaptation to digital consumer culture: A critical literature review. Journal of Consumer Behaviour, 13(2), 113-133.

Batra, R. \& Keller, K.L. (2016). Integrating marketing communications: New findings, new lessons and new ideas. Journal of Marketing, 80(6), 122-145.

Belk, R. \& Llamas, R. (2013). Living in a digital world. In: D.L. Hoffman, T.P. Novak, \& R. Stein, The Routledge Companion to Digital Consumption (pp. 28-36). New York: Routledge. 
Caban, W. (2001). Ekonomia. Podręcznik dla studiów licencjackich. Warszawa: Polskie Wydawnictwo Ekonomiczne.

Chaffey, D. (2016). Digital Business i e-Commerce Management. Warszawa: Wydawnictwo Naukowe PWN.

Chan-Olmsted, S., Cho, M. \& Lee, S. (2013). User perceptions of social media: A comparative study of perceived characteristics and user profiles by social media. Online Journal of Communication and Media Technologies, 3, 14-178. Constantinides, E. (2014). Foundations of Social Media Marketing. Procedia: Social and Behavioral Sciences, 148, 40-57.

Drucker, P. (2000). Zarzqdzanie w XXI wieku. Trans. B. Kacprzyńska. Warszawa: Muza.

Erdogmus, I. \& Cicek, M. (2012). The impact of social media marketing on brand loyalty. Procedia: Social and Behavioral Sciences, 58, 1353-1360.

Fiore, A.M. (2008). The digital consumer: Valuable partner for product development and production. Clothing and Textiles Research Journal, 26, 177-190.

Golinowska, S. (2005). Przyszłość państwa opiekuńczego i systemu zabezpieczenia społecznego. Polityka Społeczna, 11-12, 1-9.

Grębosz, M., Siuda, D. \& Szymański G. (2016). Social Media Marketing. Łódź: Monografie Politechniki Łódzkiej.

Gregor, B. \& Kaczorowska-Spychalska D. (2018). Marketing w erze technologii cyfrowych. Warszawa: Wydawnictwo Naukowe PWN.

Hatalska, N. (2008). Nie tylko wielka piątka, czyli ambient media i marketing szeptany jako alternatywne formy komunikacji. In: H. Mruk (Ed.), Reklama i PR na rozdrożu? (pp. 51-61). Poznań: Wydawnictwo Forum Naukowe.

Hootsuite \& WeAreSocial (2020). Raport Digital 2020. https://wearesocial.com/ digital-2020 (Accessed: 29 ${ }^{\text {th }}$ March 2020).

Kaplan, A. \& Haenlein, M. (2010). Users of the world, unite! The challenges and opportunities of social media. Business Horizons, 53, 59-68.

Kotler, P., Kartajaya, H. \& Setiawan I. (2017). Marketing 4.0. Warszawa: MT Biznes.

Kotler, P. \& Keller, K.L. (2013). Marketing. Poznań: Rebis.

Kreft, J. (2015). Za fasada społeczności. Kraków: Wydawnictwo Uniwersytetu Jagiellońskiego.

Krugmann, P. \& Wells, R. (2006). Mikroekonomia. Warszawa: Wydawnictwo Naukowe PWN.

Łopaciński K. \& Łysik Ł. (2016). Wpływ mediów społecznościowych i technologii mobilnych na współczesne procesy zakupowe. Informatyka Ekonomiczna = Business Informatics, 2(40), 44-57.

Mansfield, E. (2002). Podstawy mikroekonomii. Warszawa: AW Placet.

Marczak, M. (2001). Jakość a użyteczność produktu. Problemy Jakości, 3, 12-14. 
Mazurek, G. (2019). Transformacja cyfrowa. Perspektywa marketingu. Warszawa: Wydawnictwo Naukowe PWN.

Mącik, R., Mazurek, G. \& Mącik D. (2012). Channel characteristics influence on psychical vs virtual channel choice for information search and purchase: The case of Polish young customers. International Journal of Cyber Society and Education, 5, 35-54.

Milewski, R. \& Kwiatkowski, E. (2005). Podstawy ekonomii. Warszawa: Wydawnictwo Naukowe PWN.

Miotk, A. (2013). Skuteczne social media. Prowadź działania, osiagaj zamierzone efekty. Gliwice: Wydawnictwo Helion.

Mistewicz, E. (2011). Marketing narracyjny. Gliwice: Wydawnictwo Helion.

Nojszewska, E. (2010). Podstawy ekonomii. Warszawa: Wydawnictwo Szkolne i Pedagogiczne.

Olejniczuk-Merta, A. (2015). Konsumpcja czynnikiem innowacyjnego rozwoju. Marketing i Rynek, 2, 5-13.

Pikuła-Małachowska, J. (2015). Zachowania konsumpcyjne kobiet przez pryzmat zmian zachodzących w otoczeniu marketingowym. Problemy Zarzadzania, Finansów i Marketingu, 38, 67-75.

Ratalewska, M. \& Wierzbicka A. (2017) Personalizacja w Internecie - innowacyjna strategia na rynku MŚP. Przedsiębiorczość i Zarzqdzanie, 18(12), 319-333.

Rumińska-Zimny, E. (2003). Walka z ubóstwem w erze globalizacji. International Journal of Management and Economics, 14, 68-81.

Stelzner, M. (2019). 2019 Social Media Marketing Industry Report. https://www. socialmediaexaminer.com/social-media-marketing-industry-report-2019 (Accessed: $16^{\text {th }}$ December 2019).

Stephen, A.T. (2016). The role of digital and social media marketing in consumer behavior. Current Opinion in Psychology, 10, 17-21.

Urbanek, G. (2016). Marka a wartość przedsiębiorstwa na przykładzie polskich spółek giełdowych. Finanse, Rynki Finansowe, Ubezpieczenia, 1 (79), 339-348.

Woźniakowski, M. (2014). Kultura obrazkowa w komunikacji marketingowej przedsiębiorstw na przykładzie mediów społecznościowych. Marketing i Rynek, 4, 467-472.

Żarczyńska-Dobiesz, A., Chomątowska B. (2014). Pokolenie Z na rynku pracy - wyzwania dla zarządzania zasobami ludzkimi. Prace Naukowe Uniwersytetu Ekonomicznego we Wrocławiu, 350, 405-415. 


\title{
ROLA MEDIÓW SPOKECZNOŚCIOWYCH W KSZTAKTOWANIU ZACHOWAŃ ZAKUPOWYCH MKODYCH KLIENTÓW DIGITALNYCH W POLSCE
}

\begin{abstract}
Abstrakt
Tło. Dynamicznie rozwijająca się technologia i zmieniający się system komunikacji interpersonalnej wpłynęły również na zmianę podejścia klientów do procesu podejmowania decyzji zakupowych. W literaturze naukowej pojawiła się nawet koncepcja nowego klienta - klienta cyfrowego. Sytuacja na rynku zmusiła firmy do poszukiwania skutecznych, nowoczesnych narzędzi komunikacji marketingowej. Jednym z nich są media społecznościowe.

Cele badawcze. Celem artykułu jest ocena roli mediów społecznościowych w procesie zakupowym klientów cyfrowych w wieku 18-26 lat.

Metodologia. Wnioski przedstawione w artykule są wynikiem analizy badań ilościowych i jakościowych, na które złożyły się ankiety przeprowadzone wśród 140 respondentów oraz 6 indywidualnych wywiadów pogłębionych.

Wyniki badań. Przeprowadzone badania wykazały, że media społecznościowe odgrywaja istotna rolę wprocesie zakupowym młodych klientów cyfrowych. Maja one wpływ na postrzeganie marki, ale także na zakup konkretnych produktów. $\mathrm{Na}$ podstawie wyników badania można założyć, że w przyszłości rozwijane będą te funkcjonalności mediów społecznościowych, które skracają proces zakupowy, a rola tych mediów wprocesie zakupowym będzie stale rosnąć.
\end{abstract}

Słowa kluczowe: media społecznościowe, konsument digitalny, teoria wyboru konsumenta, marketing. 